\title{
Chapter 7 \\ CORPORATE REPUTATION MANAGEMENT: THEORY AND APPLIED RATING APPROACH
}

\section{Derevianko O. H.}

\section{INTRODUCTION}

The problem of research of reputation management systems (RMS) of enterprises is raised in scientific works not very frequently, being mainly a field of interest for practicing PR specialists and outsourcing consultants. In addition to the above, the following trends are obvious:

- First, the accents of scientists are shifted towards the research not of reputation management, but of the corporate reputation, towards fixing the results, but not towards determining the features (advantages and disadvantages) of the very processes of reputation building, i.e. reputation management is not considered as a process, namely, as a strategic business process of the Corporate Reputation Management. In this context, the methodological issue of the expediency of institutionalizing certain functions of reputation management in the organizational structure of an enterprise and the sufficiency (or, on the contrary, insufficiency) of a certain level of institutionalization for the fulfillment of the RMS tasks is not raised either.

- Second, a significant amount of research is devoted to the study of individual areas, i.e. tools of the reputation management system, namely PR, whereas it is necessary to take into account all the instrumental areas of RMS (PR, GR, IR, internal PR, etc.) that are parts of one system and synergistically affect the corporate reputation.

- Third, the priority of a short-term assessment is traced, a shift in the interest of scientists and practitioners towards measuring the results of specific activities (e.g. the number of publications in the mass media of necessary tonality), while further changing the attitude of stakeholders, changing their perception and shaping the target corporate reputation is not tracked in the long-term strategic perspective.

Accordingly, this research is aimed at methodological solving of these problems.

From the standpoint of the author of this research, the result of successful reputation management is the sustainable corporate 
development in the long-term (strategic) perspective. Thus, this author's position is the development of the ideas of institutional and neoinstitutional directions in economic theory. The stakeholder concept and its author's interpretation in RMS imply the need to achieve a balance of strategic objectives (sustainability of the business system as a whole) and operational objectives (financial goals of the performance of the enterprise and its stakeholders). The disclosure of the mechanisms of influence of the RMS areas and tools on business development requires in-depth attention and reasoning.

\subsection{Theoretical aspects of research methodology of corporate reputation management systems}

The task of paragraph 1 is to determine the basic theoretical aspects of the methodology for the research of corporate RMS, including: research principles, research methods, research tools, models and methods for the research of RMS and the conditions for their priority use.

Let us start with the principles of the RMS research. The basis for understanding the mechanisms of influence of reputation management on business are the Barcelona Principles ${ }^{1}$, the seven methodological guidelines for research in the field of media measurement and communication evaluation proposed by the Association for Measurement and Evaluation of Communication (AMEC) in 2010 and refined in 2015. It is recommended for all professionals working in the field of communication analysis, media measurement and PR effectiveness evaluation to consider them. This is a kind of gold standard of the industry, which was crystallized during the discussions of leading international PR associations and analytical experts. The Barcelona Principles are seven laconic guidelines and their detailed explanations, in which for each guideline several criteria for the objectivity of research, examples of metrics and professional guidelines for experts are proposed. The Barcelona Principles are as follows: 1) Goal setting and measurement are fundamental to communication and public relations. 2) Measuring communication outcomes is recommended versus only measuring outputs. 3) The effect on organizational performance can and should be measured where possible. 4) Measurement and evaluation require both qualitative and quantitative methods. 5) AVEs (advertising value equivalent) are not

\footnotetext{
${ }^{1}$ Blaze. (2019, November 6). Barcelona Declaration of Measurement Principles - AMEC: International Association for the Measurement and Evaluation of Communication. Retrieved from https://amecorg.com/2012/06/barcelona-declaration-of-measurement-principles/.
} 
the value of communication. 6) Social media can and should be measured consistently with other media channels. 7) Measurement and evaluation should be transparent, consistent and valid.

In the context of the European integration priorities of Ukraine, the necessity of bringing the theory and practice of researching the reputation management of domestic enterprises into line with the Barcelona Principles as modern standards of objectivity of research, professional guidelines for reputation managers is substantiated. At the same time, we emphasize that PR tools play an extremely important role in shaping the corporate reputation, but, at the same time, the reputation management process is not identical to public relations, and the principles of the RMS research, respectively, are broader than the principles of PR evaluation.

Attachment of the reputation of an enterprise to its strategic assets, the need for integration of reputation management into the strategic business management system and institutionalization of the reputation management function in the strategic apex of the organizational management system (OMS), proved by the author, determine whether the Balanced Score Card (BSC) method can be used for the RMS research. The main elements of the BSC are as follows:

- First, perspectives are the components with which the strategy is decomposed in order to implement it: 1) Finance (obtaining a steadily growing income - as shareholders of the company see us). 2) Clients (formation of knowledge and preferences of each client - as clients see us). 3) Processes (internal corporate processes - what stands us out among the competitors). 4) Personnel (training and development) and innovation (how we create and increase value for our clients).

- Second, objectives determine in which directions the strategy will be implemented.

- Third, measures are metrics of achievement, which should reflect progress towards a strategic goal. Indicators imply certain actions necessary to achieve the goal, and indicate how the strategy will be implemented at the operational level.

- Fourth, targets are quantitative expressions of the level to which a particular indicator should correspond.

- Fifth, cause and effect linkages should link the strategic goals of the company in a single chain in such a way that the achievement of one of them determines the progress in achieving the other (if..., then...). 
- Sixth, strategic initiatives are projects or programs that contribute to the achievement of strategic goals.

The standpoint of the author regarding the consideration of reputation management in the context of the process approach (based on the use of the system of interrelated business processes for management of the activities and resources of the reputation management) suggests the rationale for applying the methodology of this approach to the research of corporate RMS. The main point is that the business process is assessed according to the logic of transforming the "inputs" into "outputs": according to the indicators of the business process flow, indicators of the outputs (products) of the business process, indicators of customer (client) satisfaction. At the same time, the owner of the business process, the official who possesses the resources (personnel, infrastructure, software and hardware, information about the business process, etc.), controls the business process and is responsible for its results and efficiency. It is recommended to use the following standard in the RMS for describing, regulating and auditing the business process: 1) Method for describing the business process. 2) Method for regulating the business process. 3) Audit of the business process. 4) Information about the business process. 5) Regulations for the business process. 6) Report on the state of the business process (including recommendations for improving it).

Considering the above, the methods and tools of the RMS research are quite diverse and cover the areas of business process analysis, financial analysis of corporate development, statistical study of the industry/national economy, analysis of market, competition and competitiveness as well as field social research and methods of live monitoring for the development of enterprises with a particular RMS model.

Since the most widely sought-after tool (instrumental area) of RMS is PR, then, accordingly, a large number of common tools relate specifically to PR research. We emphasize that it is important to understand that the use of PR research tools is crucial, but it is not the only, and not often essential for determining the area of RMS research.

According to the International Association of Business Communicators (IABC), the method of informal observation is most often used, the next is press clipping, and the last is scientific assessment $^{2}$. At the same time, according to a study by the IPR (UK

\footnotetext{
${ }^{2}$ International Association of Business Communicators: IABC. (2019, October 22). Retrieved November 21, 2019, from https://www.iabc.com/.
} 
Institute of Public Relations) and PRCA (PR Consultants Association), with a budget of a PR project of more than 500 thousand dollars, 3-5\% of the total cost of the project should be allocated to conducting PR research, with a budget of 100-500 thousand dollars, 5-7\% respectively, with a budget of 50-100 thousand dollars, 7-10\% and for PR projects worth up to 50 thousand dollars, $10-12 \%$ of total cost should be allocated to research ${ }^{3}$. However, unfortunately, in Ukraine, the decision to conduct research is often made voluntarily, or research is generally neglected.

Let us dwell on the problems of PR research in the context of RMS. It is necessary to use the indicators of PR activity comprehensively: PR quantity and PR quality, which together testify to its effectiveness. In addition, it is necessary to evaluate the effectiveness at two levels, as determined by the Watson model ${ }^{4}$, the totals (tactical level) and the results (strategic level).

At the level of outcomes in the course of PR research, there is often an emphasis on quantitative analysis of PR activity in the media: a survey of readers and audiences, content analysis of the media, monitoring of the media (press clipping), the level of inquiries or feedback and coverage audience, analysis of statistics regarding media circulation/distribution. Quantitative indicators are also the following: the rating of goodwill (coefficient of "positive/negative mentions"); the number of self-initiated requests from journalists; appearance at a PR event. At the same time, it is extremely important not to forget about the qualitative indicators of $\mathrm{PR}$ and to investigate them: the distinguishability of PR materials (presence of noticeable illustrations, bright headlines, place on a page or web page, in a TV or radio news block, etc.); compliance of advertorials with the editorial policy of publications; compliance of the content of published PR materials with approved key messages. However, the level of outcomes is characterized by changes in the level of brand awareness (corporate, product, personal), loyalty of target categories of stakeholders and in the behavior of stakeholders.

For the analysis of the PR effectiveness, the following common methods of evaluation are used in business practice: 1) Press clipping,

\footnotetext{
${ }^{3}$ Watson, T., \& Noble, P. (2007). Evaluating public relations: a best practice guide to public relations planning, research and evaluation. London: Kogan Page.

${ }^{4}$ Watson, T., \& Noble, P. (2007). Evaluating public relations: a best practice guide to public relations planning, research and evaluation. London: Kogan Page.
} 
analysis of mentioning. 2) Content analysis. 3) Attendance and quoting of corporate Internet resources. 4) Calculation of the AVE indicator $(\mathrm{AVE}=$ Advertising Value Equivalency / Value of a PR Project). The prevalence of the latter is indicative of a certain inertia of management: note that this indicator is inherently contrary to the Barcelona Principles, but due to the comprehensibility of the calculation for top managers who have not studied the methodology of reputation management, and the inertia of the education system continues to be used because of its convenience to justify the budget parameters of PR project. Audience coverage is measured logically: the number of articles of the publication, the circulation of the publication, the number of readers per copy of the publication. In this case, distinguishability (article location, title evaluation, use of illustrations, etc.), tonality (e.g. on a scale from one to five), audience coverage (weighted result of each article is multiplied by the audience coverage indicator, i.e. the number of readers of each copy) may be taken into account. The net effect may be positive or negative, depending on the impact of the publication on the target audience. In practice, you can also determine the ratio of the desirable and negative articles.

We consider it necessary to add that in our opinion, when assessing the effectiveness of reputation management using PR tools in the media, besides the characteristics of enterprise mentioning, the following should be considered:

- Vectorness of the used PR tools, i.e. the targeting of messages to a specific audience. Any economic model is rooted in the society value system. It is clear that the value characteristics of the target audiences of an enterprise (its stakeholders) can differ significantly from each other and the same message can be perceived differently. However, an enterprise seeking to minimize reputational risks needs to achieve a positive attitude on the part of all significant target audiences. Considering this, a necessary criterion for the success of PR activities is the correspondence between the value characteristics of a message and a specific group of stakeholders, as well as the correct choice and subsequent control of information distribution channels.

- Possible synergistic effect of multi-vector information about a company, the effect of which is to reduce the PR costs in a relative manner and simultaneously increase the effectiveness of the PR service.

- The degree of message originality, as far as they stand out against the background of information produced by the PR services of other 
companies about their enterprises. Of course, the indicator of originality/creativity of messages cannot be quantified, but it can be assessed by conducting appropriate surveys, primarily among the target audience of consumers.

- Cost characteristics of PR tools used to form corporate reputation. It is possible to draw conclusions about the effectiveness of reputation management only after a cost analysis, the duration of implementation of specific PR events, economic outcomes achieved by an enterprise.

The procedures for conducting PR research are not standardized. Various author's views can be found in the literature regarding the range of parameters studied, criteria indicators and appropriate depth of evaluation. In Table 1, the author systematized the characteristics of the main models of PR evaluation as a component of the research of corporate RMS.

The relevance of searching for representative indicators of public relations effectiveness is also caused by the need to quantify the results of the company's PR service. Among PR practitioners, it is widely believed that a key criterion for the effectiveness of the company's PR department is the prevalence of its positive references. For example, information about production modernization, restructuring (if it occurs without scandals and conflicts with partners, without violating the rights of staff and non-key beneficiaries), attracted investments, etc. is considered positive. Negative information signals are associated with various manifestations of a crisis situation in an enterprise or overly diligent lobbying of their business interests. In our opinion, this approach to a certain extent one-sidedly characterizes the work of a modern PR department. First, the media space configuration has changed (a consequence of media convergence and emergence of social networks, where each individual account and blog can be a very influential micro media). Second, the importance of event PR, strategic actions, informal communication and monitoring for accumulating useful analytics is underestimated.

A separate category of evaluation practices are contests and ratings for determining effective, in the opinion of media representatives, corporate PR units and the most successful corporate PR experts, but this problem goes beyond the limits of our research. Moreover, in the opinion of the author of this research, such projects are extremely subjective and do not reflect the actual state of things due to the methodological defectiveness and bias of the individuals involved in 
evaluation. Media coverage and quality of media relations are significant, but not KPI of corporate PR services.

The PR methodology in terms of the most developed research methods and models suitable for use in the RMS is outlined by the author above and is further detailed and used to substantiate the methodology of corporate reputation management in the next paragraph of this research.

Table 1

\section{Characteristics of the main models of PR evaluation as a component of the research of corporate RMS}

\begin{tabular}{|c|c|}
\hline Model & Characteristics \\
\hline $\begin{array}{l}\text { 1. Cutlip, Center } \\
\text { and Broom } \\
\text { Research Model }\end{array}$ & $\begin{array}{l}\text { Levels and stages of PR program evaluation: } \\
\text { The highest level is impact: social and cultural } \\
\text { change; number who repeat behavior; number who } \\
\text { behave as desired; number who change attitudes; } \\
\text { number who change opinions; number who learn } \\
\text { message content. } \\
\text { The medium level is implementation: number who } \\
\text { attend to messages and activities; number who } \\
\text { receive messages and activities; number messages } \\
\text { placed and activities implemented; number of } \\
\text { messages sent to media and activities designed. } \\
\text { The low level is preparation: quality of messages and } \\
\text { activity presentation; appropriateness of message and } \\
\text { activity content; adequacy of background } \\
\text { information base for designing program. }\end{array}$ \\
\hline $\begin{array}{l}\text { 2. McNamara } \\
\text { Research Model }\end{array}$ & $\begin{array}{l}\text { Bottom-up assessment through step-by step research: } \\
\text { adequacy of background information, ability to } \\
\text { understand, research; media relevance; relevance of } \\
\text { message content; quality of message presentation } \\
\text { (for example, the design of brochure or press } \\
\text { release); number of sent messages; number of } \\
\text { messages sent to media; number of target messages; } \\
\text { number who receive messages; number who consider } \\
\text { messages; number who memorize the message } \\
\text { content (for example, increased knowledge, } \\
\text { awareness, understanding); number who change } \\
\text { attitudes; number who behave as desired; goals } \\
\text { achieved or problem solving. }\end{array}$ \\
\hline
\end{tabular}


Table 1. (Continued)

\begin{tabular}{|l|l|}
\hline 3. Simplified & $\begin{array}{l}\text { The model has a pyramid shape; Moving upward } \\
\text { Lindemann } \\
\text { Macromodel the "foundation", we examine: first, } \\
\text { introduction of data (for example, storyline and text } \\
\text { of advertising message for a newsletter, information } \\
\text { for press releases, list of speakers and event program, } \\
\text { design and content of a website); second, totals (for } \\
\text { example, newsletter, print advertising, event held, } \\
\text { website advertising); third, outcomes: (C) changes in } \\
\text { awareness, (B) changes in attitude, (A) changes in } \\
\text { behavior. }\end{array}$ \\
$\begin{array}{l}\text { Lindemann Yardstick: Final Measurement (Level 1): } \\
\text { target audience, impression, media placement; } \\
\text { Intermediate Measurement (Level 2): memorization, } \\
\text { understanding, knowledge, perception; Basic } \\
\text { Measurement (Level 3): behavior measurement, } \\
\text { attitude measurement, opinion measurement. }\end{array}$ \\
\hline Evaluation Model & $\begin{array}{l}\text { It is recommended for evaluating the PR unit activity. } \\
\text { It provides for five stages of evaluation: 1) Result } \\
\text { Stage (behavior and action); 2) Effect Stage (attitude } \\
\text { and motivation); 3) Impact Stage (awareness and } \\
\text { information); 4) Output Stage (messages and targets); } \\
\text { 5) Input Stage (planning and preparation). Tactical } \\
\text { feedback at every stage. Management feedback } \\
\text { between the first and last stages. } \\
\text { Evaluation of PR activity according to Watson: } \\
\text { output level (changes in media presence); result level } \\
\text { (changes in awareness, perception and behavior of } \\
\text { target audience). Quantitative criteria for evaluating } \\
\text { the results: number of published PR materials; } \\
\text { structure of published PR materials in terms of media } \\
\text { types; AVE taking into account the tonality of PR } \\
\text { materials. }\end{array}$ \\
\hline Development) & $\begin{array}{l}\text { It describes the change in attitude towards the object } \\
\text { of promotion, depending on the level of activity. } \\
\text { 1. The negative attitude is changed to susceptible and } \\
\text { then to publicly positive only under the condition of } \\
\text { constantly and often implemented proactive contact. } \\
\text { 2. Proactive contact: from occasional to fairly } \\
\text { regular, then, constant and frequent. Attitude to the } \\
\text { object or perception of the object of PR promotion: } \\
\text { negative, receptive, publicly positive. }\end{array}$ \\
\hline
\end{tabular}


Table 1. (Ending)

\begin{tabular}{|l|l|}
\hline 6. Spatial Model & Evaluation by four vectors: 1) Number (number of \\
for Evaluating PR & published PR materials, their volume; mentioning, \\
Activity in Media & number of key messages); 2) Time (historical \\
& $\begin{array}{l}\text { comparison; comparison with competitors; } \\
\text { comparison of goals; benchmarking); 3) Central }\end{array}$ \\
parameters (media source, media sector, all media); \\
4) Quality (circulation; audience; attribution; \\
perception (+, 0, -); impact; message strength). \\
256 analysis options.
\end{tabular}

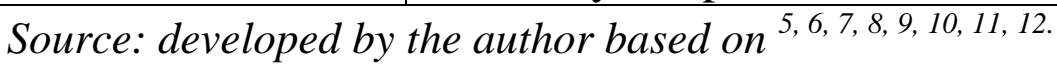

\subsection{Methodological bases of the national quality rating of corporate reputation management (reputation of enterprises)}

In the context of the European integration priorities of Ukraine, domestic enterprises need to realize the importance of reputation assets as a factor in the global competitiveness not only of their business, but of the whole of our country. In world practice, an effective tool that stimulates a business to systemic management of its own reputation is public rating built on the basis of periodic analysis of the reputation management quality of various enterprises (leaders in their industries) by independent experts.

In 2015, to solve these reputation tasks facing the Ukrainian business, the Reputation ACTIVists (http://repactiv.com.ua) national rating of the corporate reputation management quality was introduced and held on an annual basis. The rating is aimed at identifying effective management models and further highlighting the unique experience of the winning company in order to popularize high-quality reputation management. The long-term goal of the rating is to form the reference

\footnotetext{
${ }^{5}$ Watson, T., \& Noble, P. (2007). Evaluating public relations: a best practice guide to public relations planning, research and evaluation. London: Kogan Page.

${ }_{7}^{6}$ Dowling, G. R. (2016). Winning the reputation game. Cambridge, MA: The MIT Press.

${ }^{7}$ Broom, G. M., Cutlip, S. M., \& Center, A. H. (2009). Effective public relations. New Jersey: PrenticeHall.

${ }^{8}$ Dowling, G. (2009). Creating corporate reputations identity, image, and performance. Oxford: Oxford Univ. Press.

${ }^{9}$ Lindenmann, W. K. (1998). Only PR outcomes count - That is the real bottom line. Journal of Communication Management, 3(1), 66-73. doi: 10.1108/eb023485

${ }^{10}$ Macnamara, J. (1992). Evaluation of public relations: The Achilles heel of the PR profession. The International Public Relations Review, 15 (2), 19.

${ }^{11}$ Fombrun, C. J., \& Riel, C. B. M. van. (2003). Fame and fortune: how the worlds top companies develop winning reputations. Upper Saddle River, NJ: Pearson Education.

${ }_{12}$ Gregory, A. (2015). Planning and managing public relations campaigns: a strategic approach. London: Kogan Page.
} 
systems of reputation management in domestic enterprises, certain national standards for high-quality reputation management.

One of the most well-known foreign reputation assessment tools, as already noted, is the Global RepTrak ${ }^{\circledR}$ rating $^{13}$ and its modifications developed by the global consulting company Reputation Institute. The world-class authority on reputation management is Charles Fombrun ${ }^{14}$, founder and chairman of the Reputation Institute. Leonard J. Ponzi and William Newberry ${ }^{15}$, Rita Linjuan Men ${ }^{16}$, Thomas Muller ${ }^{17}$, etc. also pay great attention to reputation assessment issues. Major consulting companies conduct research on the reputation and factors of its building in different countries: Accenture ${ }^{18}$, British Research Company Millward Brown (part of the WPP communication group) ${ }^{19}$, the world leader in public relations, Edelman ${ }^{20}$, etc. Note that the analysis of the methodology of the aforementioned foreign studies is a necessary but not sufficient condition for substantiating methodological basis of national reputation rating.

In this paragraph, the general purpose of the research is to highlight the results of the author's research on the substantiation of the methodological basis of the National Quality Rating of Corporate Reputation Management in Ukraine.

Reputation management, like any managerial process, implies a focus on achieving goals. The a priori strategic goal of such management is to form and maintain the trust of key stakeholders of an enterprise. However, the tasks of the functional level that are subordinate to this goal may significantly vary depending on the development conditions of a particular company, the situation of its markets, and the socio-political context of its home base country. Thus, assessing the

\footnotetext{
${ }^{13}$ Fombrun, C. J., Ponzi, L. J., \& Newburry, W. (2015). Stakeholder Tracking and Analysis: The RepTrak ${ }^{\circledR}$ System for Measuring Corporate Reputation. Corporate Reputation Review, 18(1), 3-24. doi: 10.1057/crr.2014.21

${ }^{14}$ Fombrun, C. J., \& Riel, C. B. M. van. (2003). Fame and fortune: how the worlds top companies develop winning reputations. Upper Saddle River, NJ: Pearson Education.

${ }_{15}$ Fombrun, C. J., Ponzi, L. J., \& Newburry, W. (2015). Stakeholder Tracking and Analysis: The RepTrak ${ }^{\circledR}$ System for Measuring Corporate Reputation. Corporate Reputation Review, 18(1), 3-24. doi: 10.1057/crr.2014.21

${ }_{16}$ Men, L. R. (2014). Internal Reputation Management: The Impact of Authentic Leadership and Transparent Communication. Corporate Reputation Review, 17(4), 254-272. doi: 10.1057/crr.2014.14

17 Mueller, T. S. (2014). Consumer Perception of CSR: Modeling Psychological Motivators. Corporate Reputation Review, 17(3), 195-205. doi: 10.1057/crr.2014.9

${ }_{18}$ Carreras, E., Alloza Ángel, \& Carreras, A. (2014). Corporate reputation. London: LID Publishing Ltd.

${ }^{19}$ BrandZ Top 100 Most Valuable Global Brands. (n.d.). Retrieved November 21, 2019, from http://www.millwardbrown.com/brandz/rankings-and-reports/top-global-brands/2019.

${ }_{20}$ Brandshare ${ }^{\mathrm{TM}}$ 2014. (n.d.). Retrieved November 20, 2019, from https://www.edelman.com/research/ brandshare-2014.
} 
company's efforts to build its reputation, it is necessary to distinguish two vectors of such an assessment: functional (assessment of management processes) and resultant (direct assessment of established reputation - trust).

At the functional level, taking into account the existing business development trends, the goals of corporate reputation management can be formulated as follows:

- Maintaining the stability of corporate reputation by systematically managing it on the basis of the compliance of the shareholders' ideas about a company with the real economic characteristics of its activities (quality/price of the company's products, introduction of new technologies, business development dynamics, etc.). Let us call this goal "reputational stability".

- Raising the level of awareness of stakeholder audience about the company's activities based on the principles of its openness for communication with journalists, the high quality of information disseminated by/about a company in the media, as well as the promptness of neutralizing information risks by a company. Let us call this goal "media activity".

- Enhancing the distinctiveness of a company from its competitors while increasing its level of awareness by stakeholders based on the development of PR innovations, the company's new media activities, and the effective implementation of innovative PR practices. This goal will be integrated as an innovative approach to reputation management.

- Strengthening the social significance of a company through the introduction of transparent procedures and practices of corporate social responsibility (CSR), the initiation of socially significant projects and the introduction of socially responsible organization of internal business processes. That is, the formation and enhancement of "CSR image capital".

- Avoiding a crisis by forming a balanced crisis response strategy, integrated use of anti-crisis PR tools by a company in order to disengage from projects/events that are doubtful from a reputational point of view. That is, the anti-crisis function of reputation management.

To implement the idea of assessing the relevant reputation management processes, the following functional nominations have been introduced: Reputational Stability, Media Activity, Innovative Approach, CSR Image Capital, and Anti-Crisis Sustainability.

When evaluating reputation management, it is necessary to remember that it consists of certain obligatory elements, i.e. it is a 
system. The author's vision of corporate reputation management system is described in more detail in publications ${ }^{21},{ }^{22}$. Let us dwell on the main point. The three-dimensional nature of the reputation management system is fundamental: first, the presence of reputation management foundation (PR department, approved reputation building strategy, authority to form corporate information policy for PR managers, etc.); second, the arsenal of reputation building tools used, the breadth of such an arsenal, the regularity and skills of its use (PR, GR, IR, CSR and other reputational activities); third, supporting feedback, monitoring the attitude to a company and taking into account the views of stakeholder audience to improve the corporate reputation management processes.

Note that at the level of each of the five functional nominations, all three dimensions of the reputation management system (Tables 3.5-3.9) are assessed: "foundation" - institutionalized functions (I), "reputational activities" (A) and stakeholder feedback mechanisms (C): the first criterion is I (presence, that is, institutionalization, a key for the nomination function of reputation management); the second and third criteria are A (reputation management tools, the most representative for this nomination); the fourth and fifth criteria are $\mathrm{C}$ (communication is the reaction of stakeholders).

Evaluation within the framework of the proposed five nominations is carried out by questioning of experts, which is traditional for researching the quality of reputation management in world practice. According to the proposed method, each criterion is decomposed in the format of a set of estimated indicators and features on a scale from 0 to 10. All indicators have equal weight (see Tables 2-6).

In order to avoid conflicts of interest and ensure objectivity of the rating, experts exclusively external to the nominee companies are involved in the pool of experts: the most authoritative media experts of the country, independent industry experts and representatives of consulting companies, investment analysts, representatives of professional public organizations uniting relevant operators markets. The list of jury members is available to the public (http://repactiv.com.ua/ru/experts). If, however, there is a conflict of interest in relation to any of the nominee companies, the expert shall withdraw its name. In the course of assessing

\footnotetext{
${ }^{21}$ Derevyanko, O. (2018). Theoretical framework for corporate reputation management within the context of the modern paradigm of management. Strategy of Economic Development of Ukraine, 43, 21-35. doi: 10.33111/sedu.2018.43.021.035

${ }^{22}$ Derevianko, O. (2014) System of enterprise reputation management. Business Inform, 3, 381-386.
} 
a nominee company, an expert may consider it incorrect to assess any indicator (due to the lack of judgment on this issue) and leave the cell blank. Note that experts give an assessment cumulatively - not for a specific period, but as the cumulative result of reputational achievements or failures of a company obtained during its entire history at a given time.

Given the hypothesis that high-quality reputation management should leave a noticeable mark in the information space, companies with the highest media coverage rate are selected to participate in the rating. Using the specialized search engines covering thousands of local and foreign sources, statistics of mentioning of each company is investigated (to determine indicators of mentioning in the media in the context of each of the markets). Based on the results, media leaders are determined by each market, and the number of nominee companies may vary depending on the degree of economic concentration in a particular market and the presence/absence of a statistically significant gap in media mentioning indicators. The opinion of industry associations, partners and experts is taken into account during the selection of nominees.

Then a survey is held (assessment of nominee companies by experts on the website http://repactiv.com.ua), the results of which form the rating of odds-on favorites, i.e., mathematically, after determining the amount of expert points of each company in each nomination, they are sorted in descending order within each individual nomination. This mathematical procedure is automated and carried out on the website http://repactiv.com.ua. The result is a rating of winners (companies with different industry affiliations) in each of the nominations: Reputational Stability, Media Activity, Innovative Approach, CSR Image Capital, Anti-Crisis of the Year.

The leadership of an enterprise in a certain nomination of the National Quality Rating of Corporate Reputation Management, highly appreciated by experts in building reputation, indicates the prerequisites for a serious generalizing result - the established reputation of an enterprise. However, in practice, high results not often arise out of tremendous efforts: some enterprises win reputational leadership without exerting great effort, inventing cost-effective and at the same time effective models of reputation management. One of the objectives of the National Quality Rating of Corporate Reputation Management is to identify such effective models and further highlight the unique experience of the winning company in order to popularize high-quality reputation management capable of raising business in Ukraine to high international standards. 


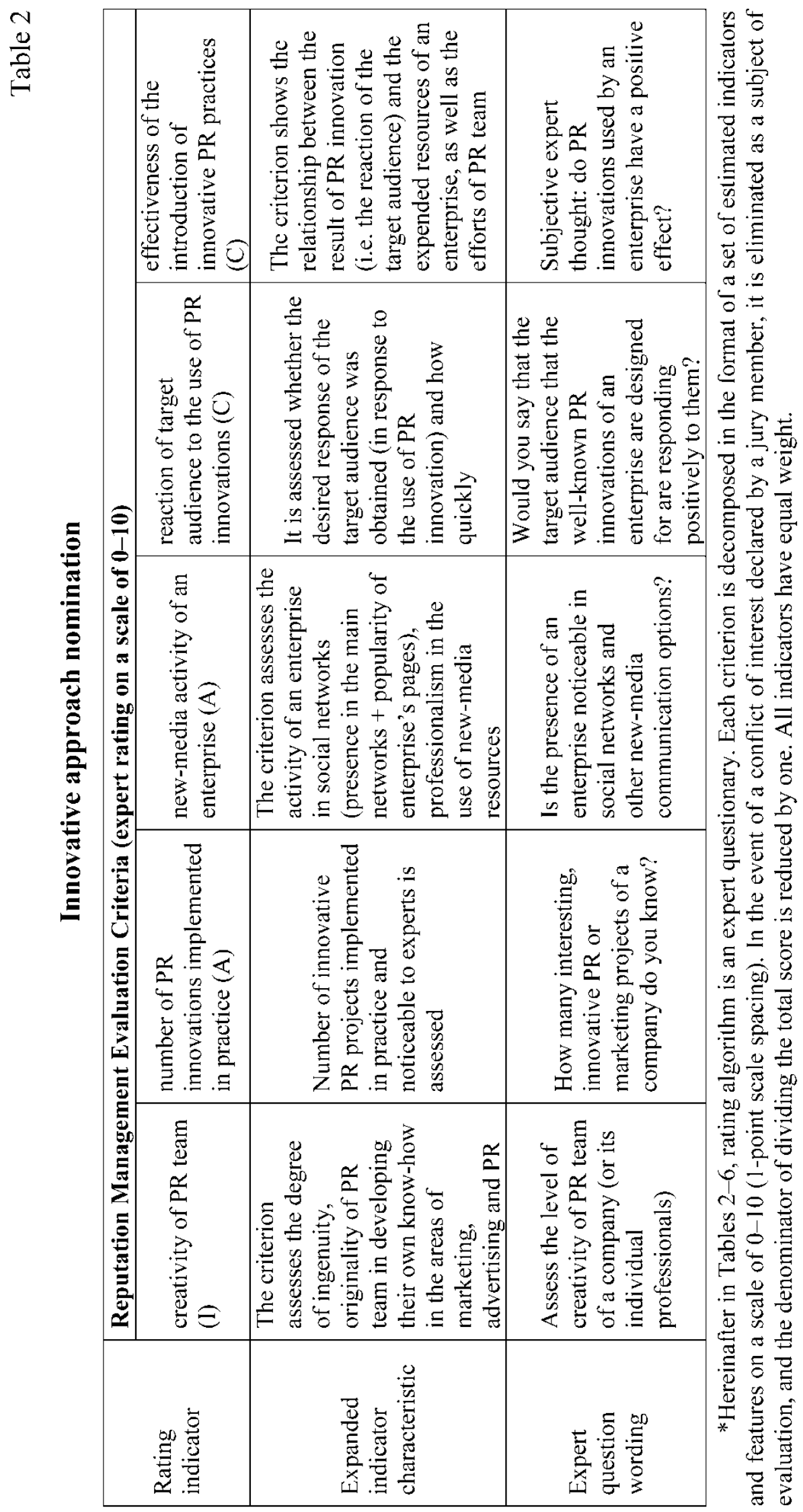




\begin{tabular}{|c|c|c|c|}
\hline \multirow{6}{*}{ 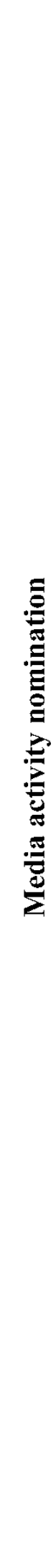 } & 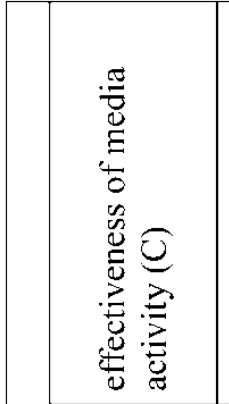 & 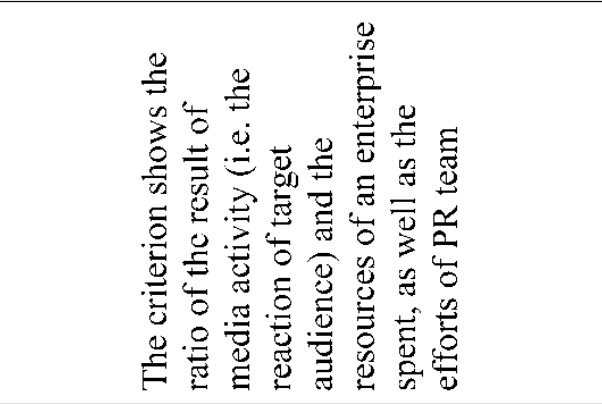 & 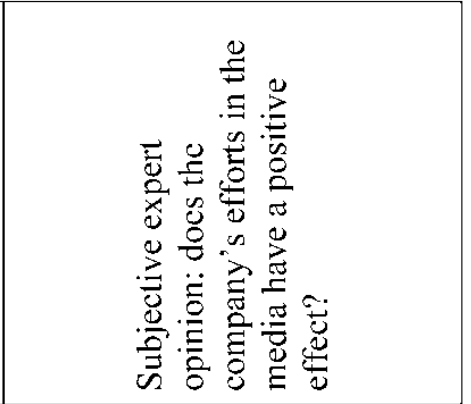 \\
\hline & 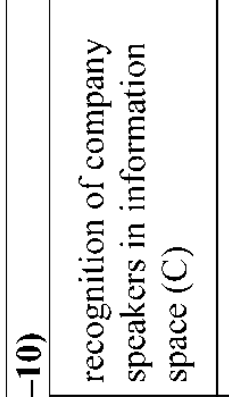 & 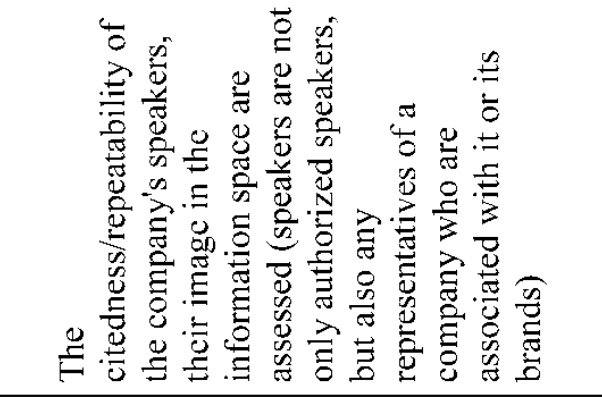 & 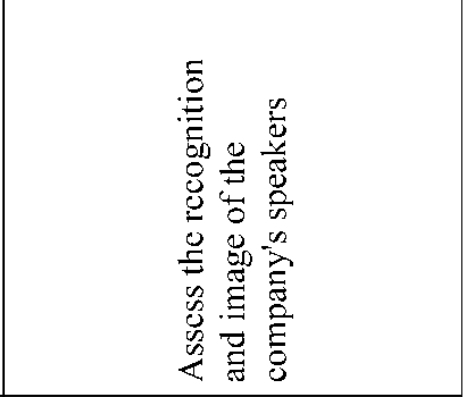 \\
\hline & 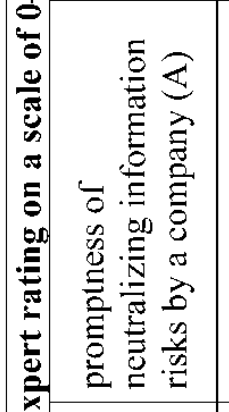 & 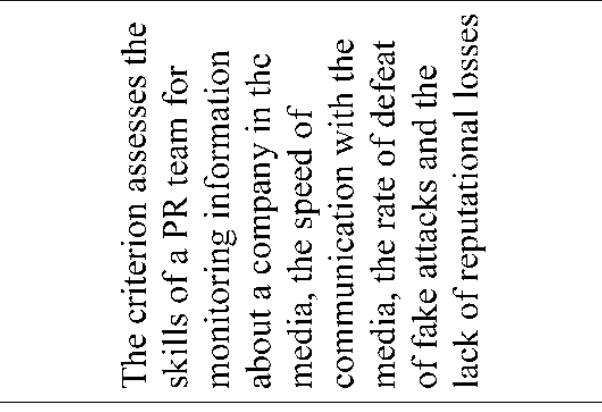 & 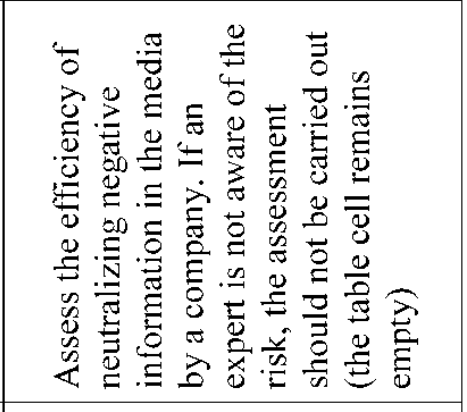 \\
\hline & 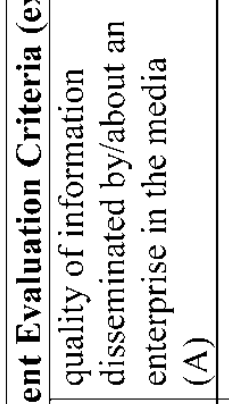 & 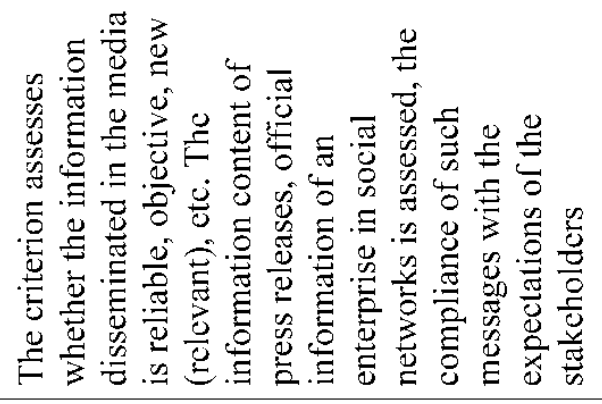 & 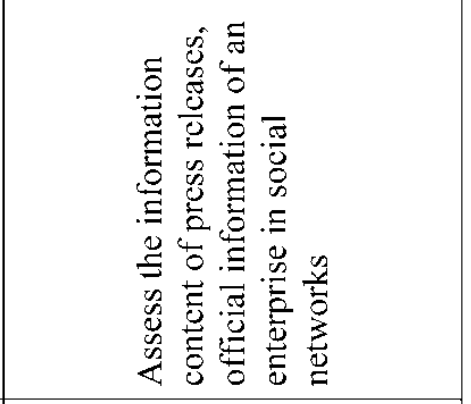 \\
\hline & 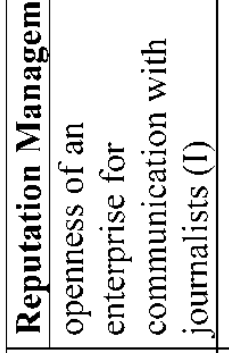 & 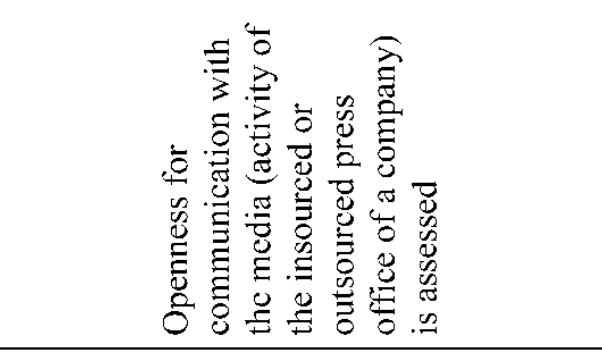 & 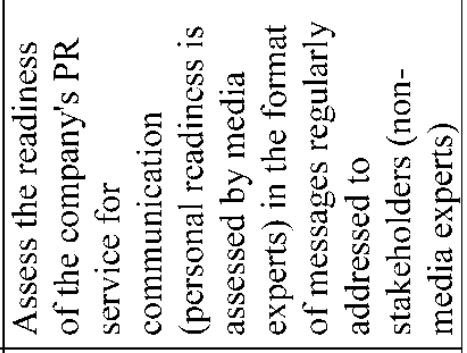 \\
\hline & 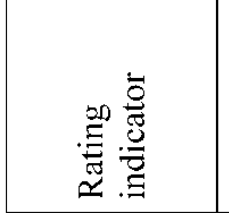 & 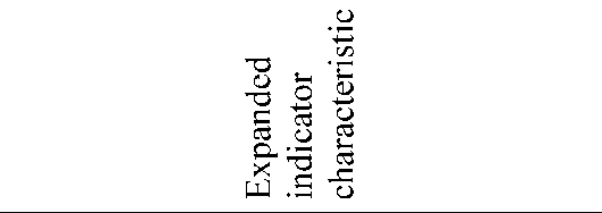 & 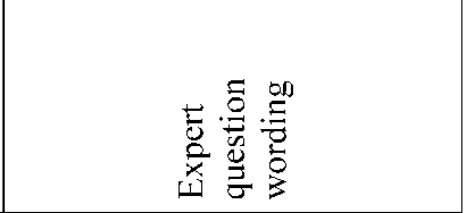 \\
\hline
\end{tabular}




\begin{tabular}{|c|c|c|c|}
\hline & 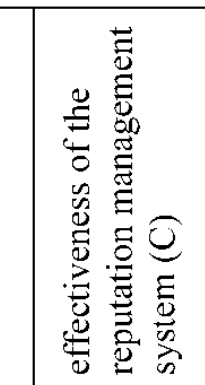 & 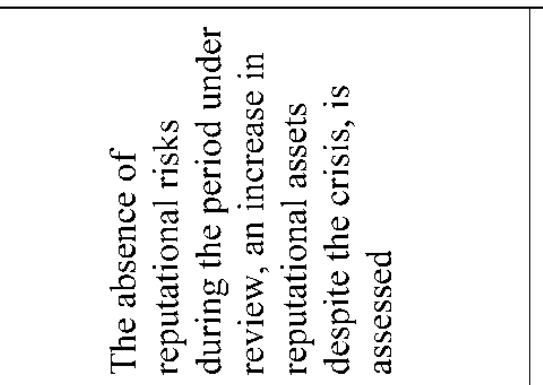 & 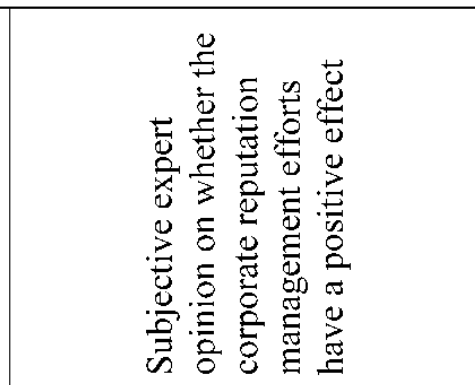 \\
\hline & 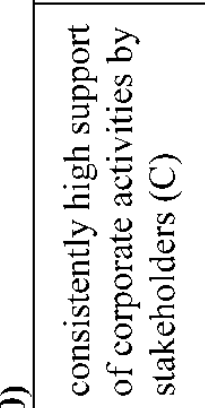 & 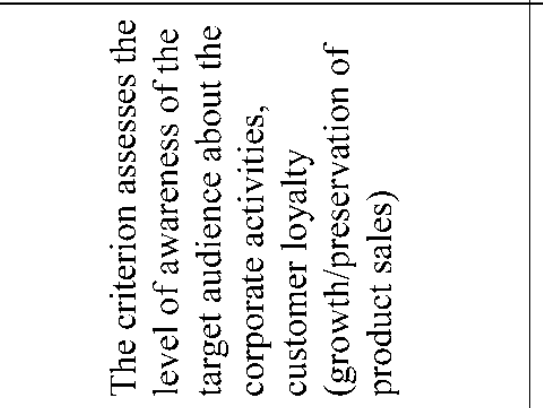 & 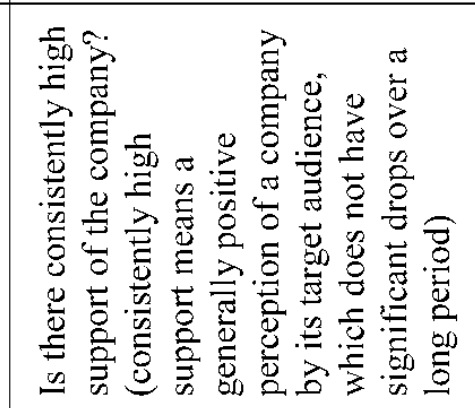 \\
\hline | & 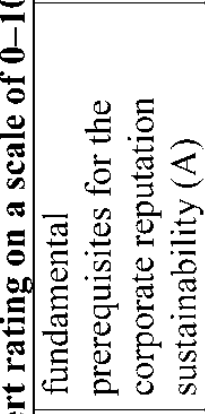 & 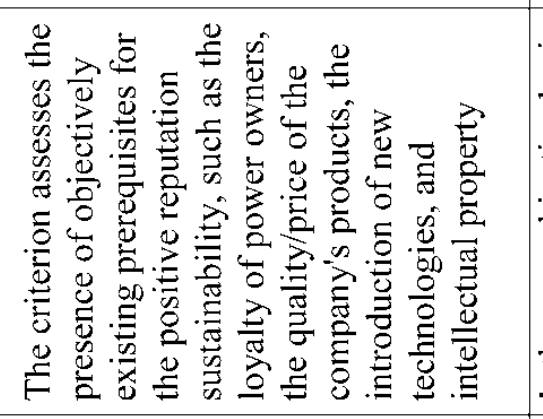 & 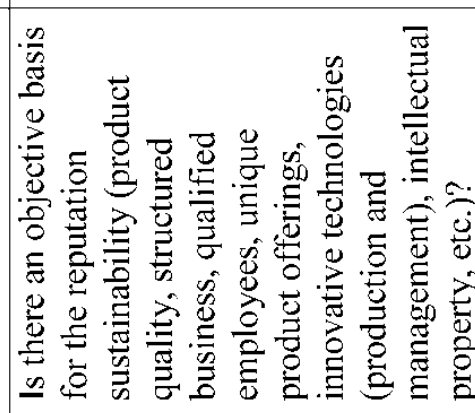 \\
\hline . & 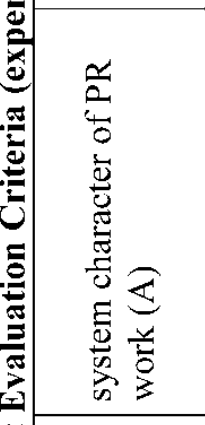 & 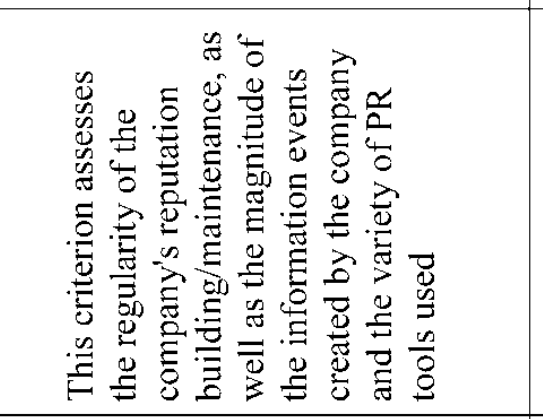 & 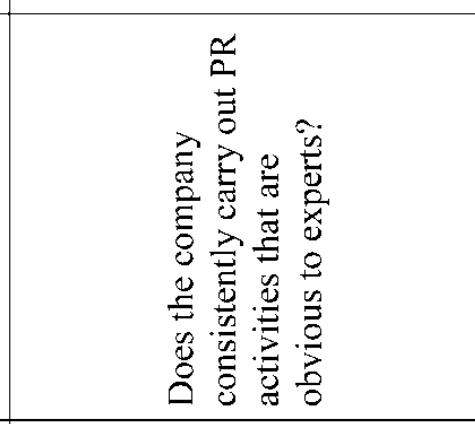 \\
\hline & 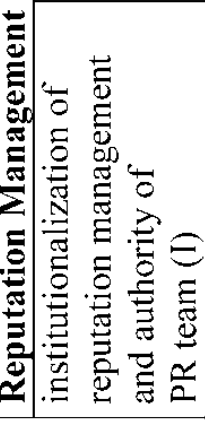 & 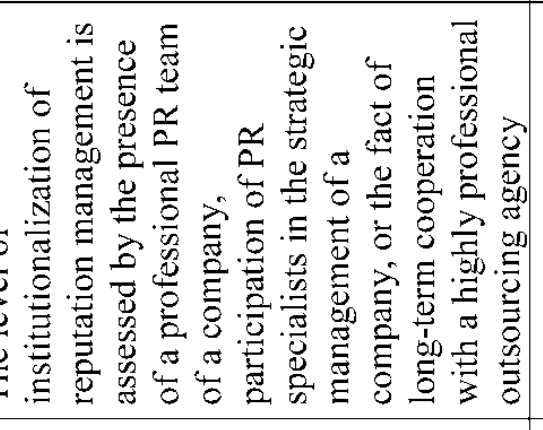 & 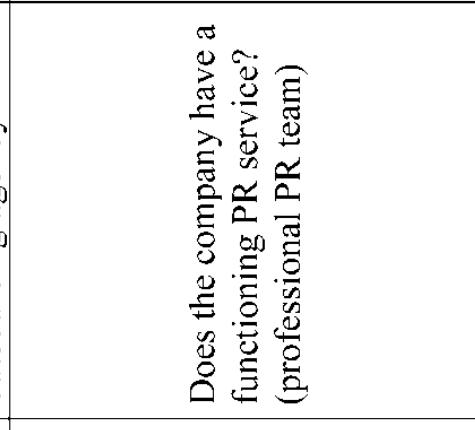 \\
\hline & 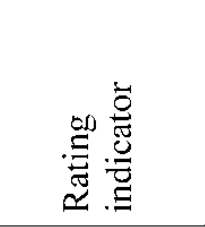 & 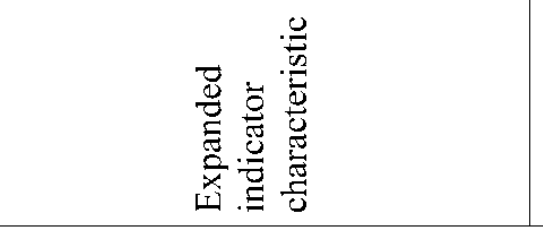 & 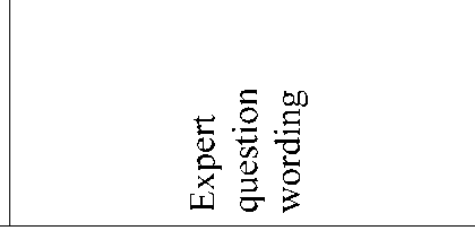 \\
\hline
\end{tabular}




\begin{tabular}{|c|c|c|c|c|}
\hline \multirow{6}{*}{ 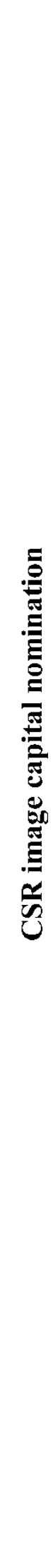 } & & 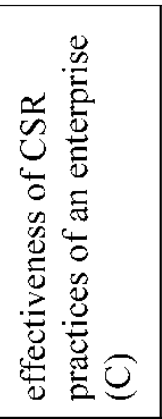 & 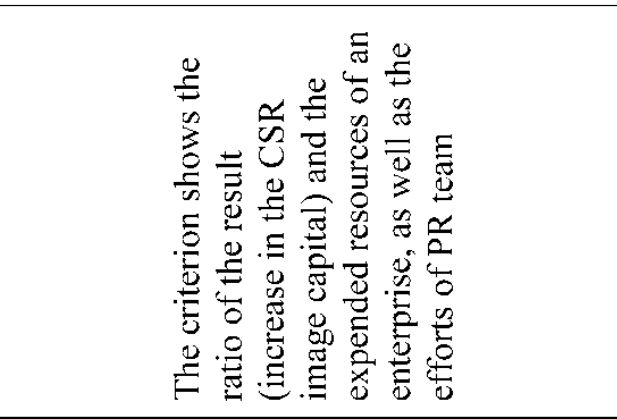 & 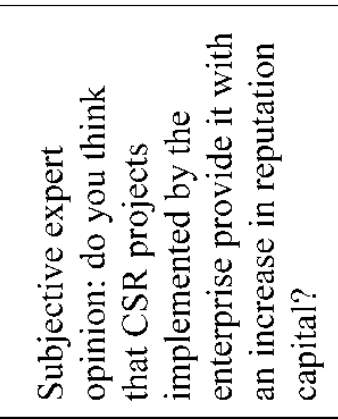 \\
\hline & - & 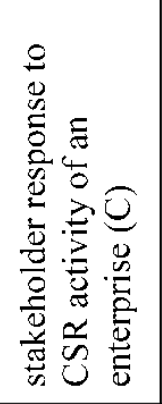 & 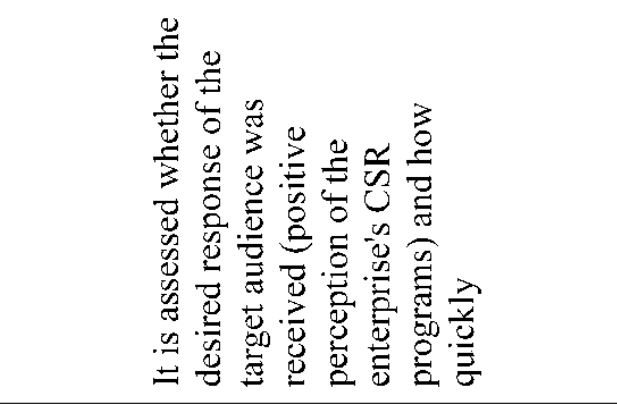 & 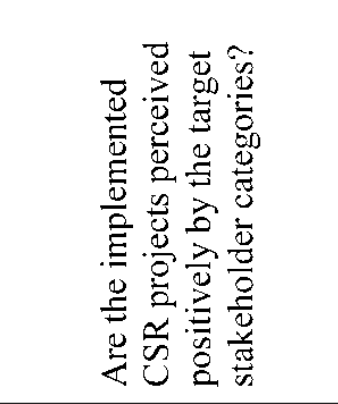 \\
\hline & 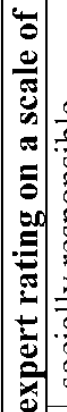 & 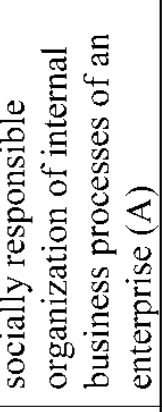 & 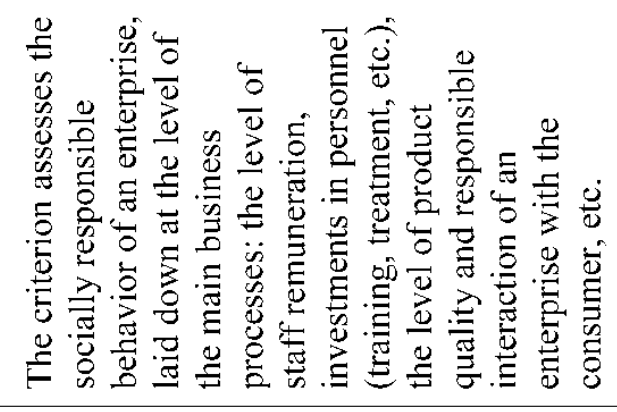 & 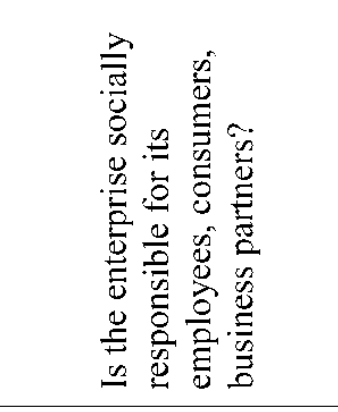 \\
\hline & 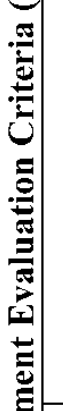 & 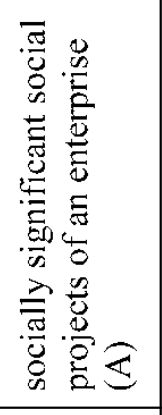 & 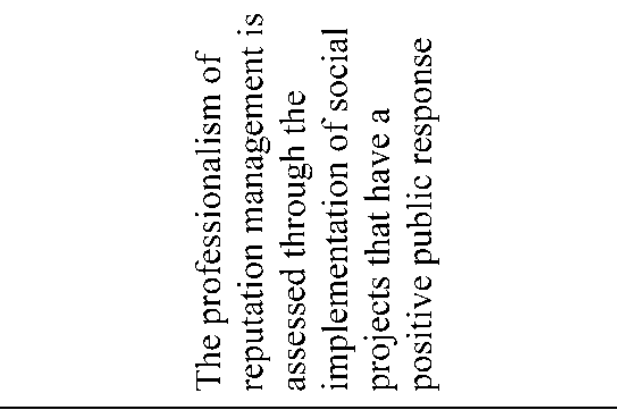 & 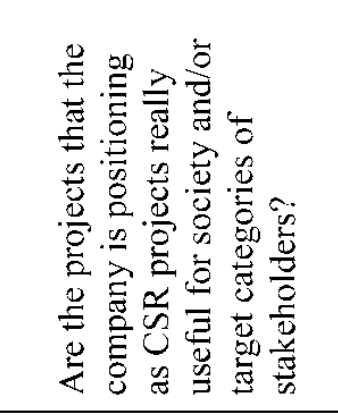 \\
\hline & | & 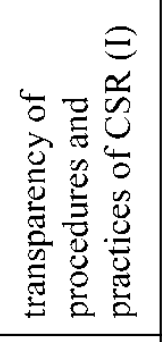 & 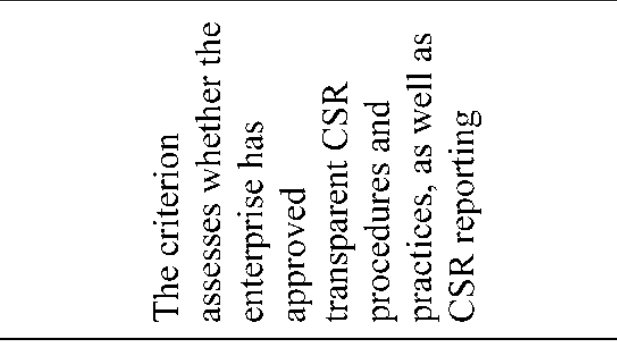 & 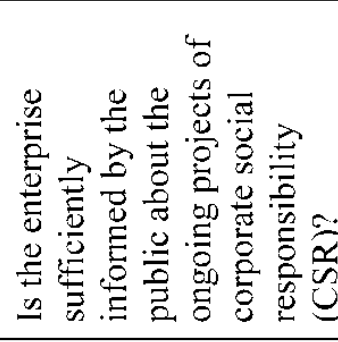 \\
\hline & & 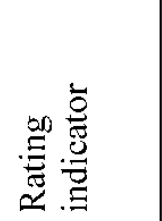 & 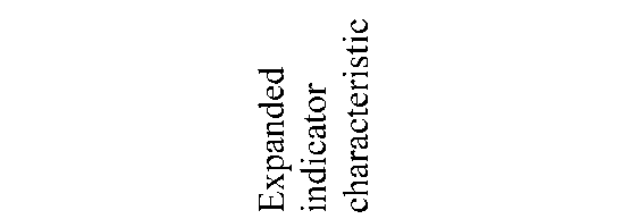 & 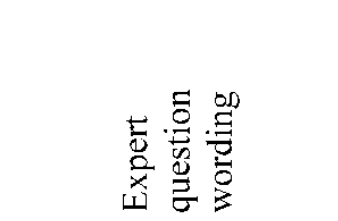 \\
\hline
\end{tabular}




\begin{tabular}{|c|c|c|c|c|}
\hline \multirow{6}{*}{ 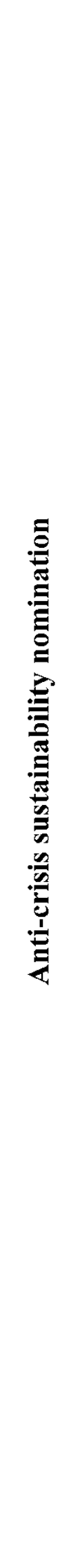 } & & 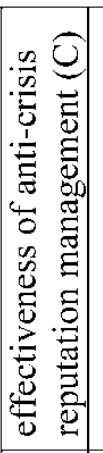 & 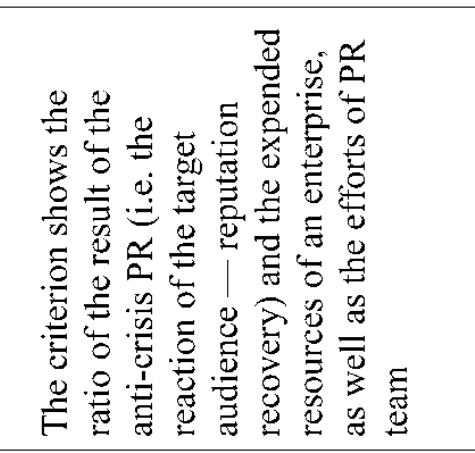 & 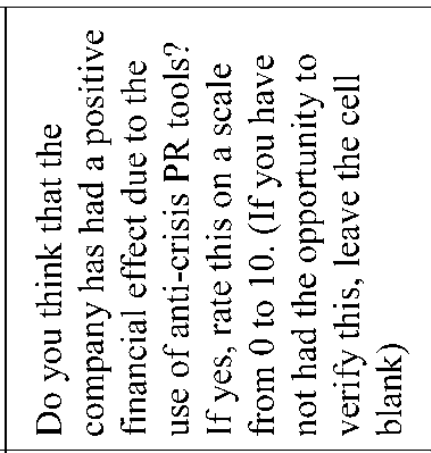 \\
\hline & & 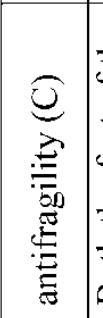 & 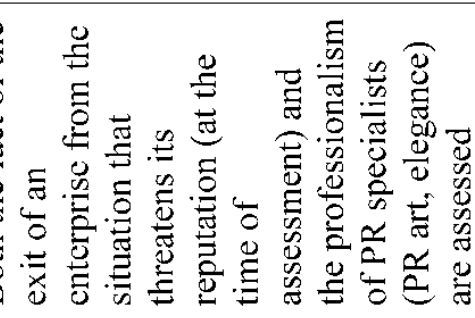 & 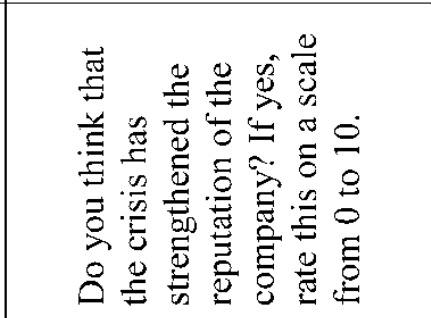 \\
\hline & 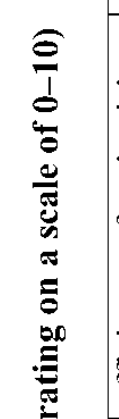 & 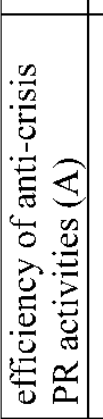 & 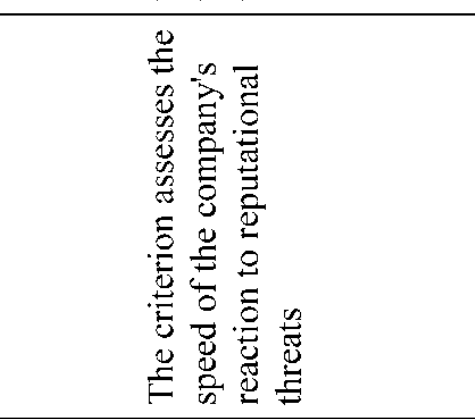 & 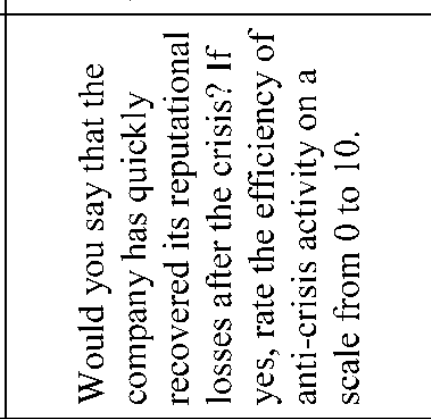 \\
\hline & 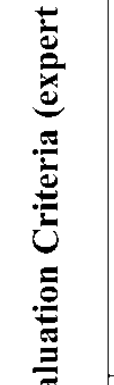 & 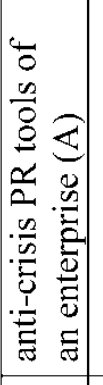 & 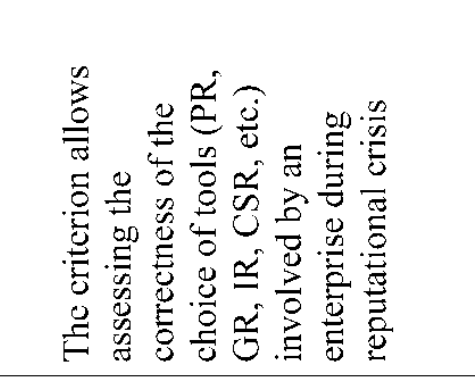 & 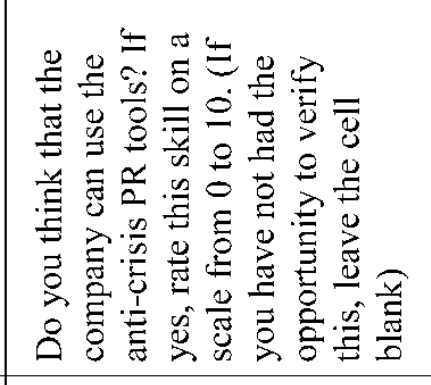 \\
\hline & 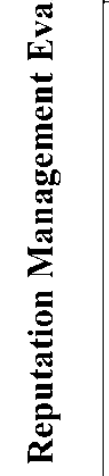 & 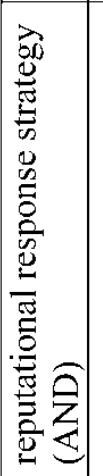 & 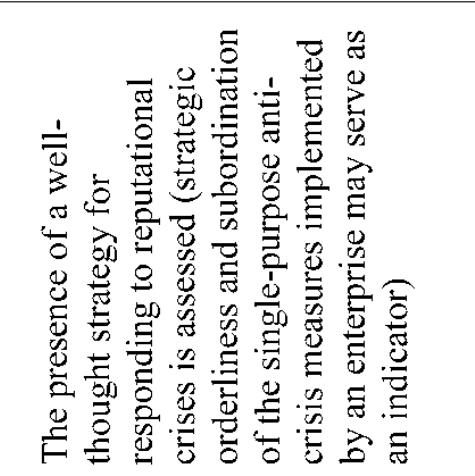 & 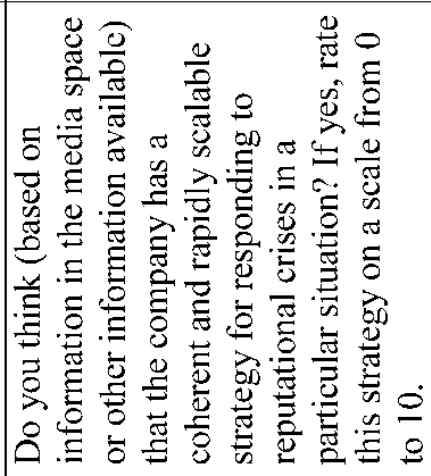 \\
\hline & & & x. & 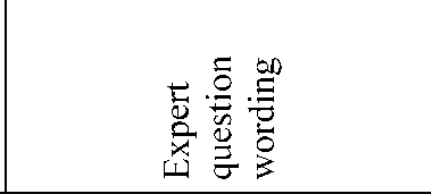 \\
\hline
\end{tabular}


Winners of the National Quality Rating of Corporate Reputation Management are awarded at the annual International PR Festival (http://pr-festival.com.ua) and it is positioned as a way to mark the achievements of enterprises (both domestic and Ukrainian business units of international corporations) in reputation management.

Starting from 2015, the annual rating reveals winners in the context of specific sectors of the Ukrainian economy (winners of industry nominations) and intersectoral leaders in one or another area of work with reputation assets of an enterprise (winners of functional nominations).

During the expert voting for three years of research, the most important regularity was revealed: systematic work with corporate reputation allows not only increasing the reputational capital, but also preserving it for a long enough period. For three years (2015-2017), the rating leaders have been the same in such nominations as FMCG, NonFood (Procter\&Gamble), Oil Refining and Retail (OKKO) and Electricity Generation (DTEK). Despite the fact that all the listed companies operate in industries that significantly differ from each other in information activity, competition format and level of consolidation, they have quite a few common characteristics. This, above all, is about the integrity of reputation management and understanding the importance of this area of work.

There were quite a few companies that won the leadership for the second year in a row among the leaders in their industry nomination in April 2017: AXA Insurance (Insurance Companies), Microsoft (IT. Soft), MTI (Fashion), Comfy (Electronics), Epicenter (Homeware). In addition, the enterprises that received recognition of the expert community earlier in 2015 became the leaders of the rating: Alfa-Bank Ukraine, Kyivstar, Kievgorstroy and Neftegazdobycha. Successful models of reputation management of these companies are an example for other participants of the Ukrainian market and are widely popularized by the organizers of the National Quality Rating of Corporate Reputation Management within the framework of the annual International PR Festival.

Functional nomination of the rating allows identifying interindustry leaders, and in 2017, Carlsberg Ukraine won the Reputational Stability nomination. The fact that the company retains leadership in this category for the second year in a row confirms the stability of its reputation management model. In 2015, when the rating was held for the 
first time, Carlsberg Ukraine became the leader in the Innovative Approach nomination.

Leadership in the Innovative Approach nomination is the prerogative of companies actively competing for the recognition of stakeholders and, above all, for the recognition of consumers. In 2017, as the year before, Ukrainian restaurateurs were recognized as the best innovators. This time, GastroFamily by Dima Borisov was the first in the rating. The construction sector is actively struggling for the buyer, and Kievgorstroy has become the leader in the Media Activity nomination for the third year in a row.

The very specificity of the fight against reputational crises, which are always unique, determines that year by year the leaders in the AntiCrisis Sustainability category are not the same. For a similar reason, you can see new leaders in the CSR Image Capital nomination every year. The dynamics of the National Quality Rating of Corporate Reputation Management testifies that introducing the reputation management system in domestic enterprises is underway, although not at a fast pace.

\section{CONCLUSIONS}

The problem of research of reputation management systems (RMS) of enterprises is raised in scientific works fragmentarily: first, the accents of scientists are shifted towards the research not of reputation management, but of the corporate reputation, towards fixing the results, but not towards determining the features (advantages and disadvantages) of the very processes of reputation building, i.e. reputation management is not considered as a process, namely, as a strategic business process of the Corporate Reputation Management; second, a significant amount of research is devoted to the study of individual areas, i.e. tools of the reputation management system, namely PR, whereas it is necessary to take into account that all the instrumental areas of RMS (PR, GR, IR, internal PR, etc.) are parts of one system and synergistically affect the corporate reputation; third, the priority of a short-term assessment is traced, a shift in the interest of scientists and practitioners towards measuring the results of specific activities (e.g. the number of publications in the mass media of necessary tonality), while further changing the attitude of stakeholders, changing their perception and shaping the target corporate reputation is not tracked in the long-term strategic perspective. 
The methodological foundations of the National Quality Rating of corporate reputation management (i.e. the reputation of enterprises and their associations) proposed by the author are highlighted. Assessing the efforts of companies to build their reputation, it is necessary to distinguish between two vectors of such an assessment: functional (assessment of management processes) and resultant (direct assessment of established reputation - trust). The following functional nominations are introduced: Reputational Stability, Media Activity, Innovative Approach, CSR Image Capital, and Anti-Crisis Sustainability.

\section{SUMMARY}

Based on the analysis of scientific publications and theories, the author of this research proposed and implemented the National Quality Rating of Corporate Reputation Management (i.e. the reputation of companies and their associations) in order to bring the level of reputation management of domestic enterprises in line with high international standards. Assessing the efforts of companies to build their reputation, it is necessary to distinguish between two vectors of such an assessment: functional (assessment of management processes) and resultant (direct assessment of established reputation - trust). At the functional level, the following functional nominations have been introduced: Reputational Stability, Media Activity, Innovative Approach, CSR Image Capital, and Anti-Crisis Sustainability. Given the hypothesis that high-quality reputation management should leave a noticeable mark in the information space, companies with the highest media coverage rate are selected to participate in the rating, and statistics on mentioning of each enterprise is examined. Evaluation within the proposed five nominations is carried out by questioning independent experts. The development of conceptual and methodological foundations of formation of reputation management of enterprises presented in this research significantly improve the quality and effectiveness of management and ensure the sustainability and predictability of corporate development.

\section{REFERENCES}

1. 2019 BrandZ Top 100 Most Valuable Global Brands. (n.d.). Retrieved November 21, 2019, from http://www.millwardbrown.com/ brandz/rankings-and-reports/top-global-brands/2019. 
2. Blaze. (2019, November 6). Barcelona Declaration of Measurement Principles - AMEC: International Association for the Measurement and Evaluation of Communication. Retrieved from https://amecorg.com/2012/06/barcelona-declaration-of-measurementprinciples/.

3. Brandshare ${ }^{\mathrm{TM}}$ 2014. (n.d.). Retrieved November 20, 2019, from https://www.edelman.com/research/brandshare-2014.

4. Broom, G. M., Cutlip, S. M., \& Center, A. H. (2009). Effective public relations. New Jersey: Prentice-Hall.

5. Carreras, E., Alloza Ángel, \& Carreras, A. (2014). Corporate reputation. London: LID Publishing Ltd.

6. Derevianko, O. (2014) System of enterprise reputation management. Business Inform, 3, 381-386.

7. Derevyanko, O. (2018). Theoretical framework for corporate reputation management within the context of the modern paradigm of management. Strategy of Economic Development of Ukraine, 43, 21-35. doi: 10.33111/sedu.2018.43.021.035

8. Dowling, G. (2009). Creating corporate reputations identity, image, and performance. Oxford: Oxford Univ. Press.

9. Dowling, G. R. (2016). Winning the reputation game. Cambridge, MA: The MIT Press.

10. Fombrun, C. J., \& Riel, C. B. M. van. (2003). Fame and fortune: how the worlds top companies develop winning reputations. Upper Saddle River, NJ: Pearson Education.

11. Fombrun, C. J., Ponzi, L. J., \& Newburry, W. (2015). Stakeholder Tracking and Analysis: The RepTrak ${ }^{\circledR}$ System for Measuring Corporate Reputation. Corporate Reputation Review, 18(1), 3-24. doi: 10.1057/crr.2014.21

12. Gregory, A. (2015). Planning and managing public relations campaigns: a strategic approach. London: Kogan Page.

13. International Association of Business Communicators: IABC. (2019, October 22). Retrieved November 21, 2019, from https://www.iabc.com/.

14. Lindenmann, W. K. (1998). Only PR outcomes count - That is the real bottom line. Journal of Communication Management, 3(1), 66-73. doi: 10.1108/eb023485

15. Macnamara, J. (1992). Evaluation of public relations: The Achilles heel of the PR profession. The International Public Relations Review, 15 (2), 19. 
16. Men, L. R. (2014). Internal Reputation Management: The Impact of Authentic Leadership and Transparent Communication. Corporate Reputation Review, 17(4), 254-272. doi: 10.1057/crr.2014.14

17. Mueller, T. S. (2014). Consumer Perception of CSR: Modeling Psychological Motivators. Corporate Reputation Review, 17(3), 195-205. doi: 10.1057/crr.2014.9

18. Watson, T., \& Noble, P. (2007). Evaluating public relations: a best practice guide to public relations planning, research and evaluation. London: Kogan Page.

\section{Information about the author:} Derevianko O. H. Doctor of Economic Sciences, Associate Professor, Department of Economics, Accounting and Finance, National University of Food Technologies, Ukraine ORCID: https://orcid.org/0000-0002-1857-2862 